\title{
Evaluation of the Therapeutic Response and Improvement in the Quality of Life of the Patient with Darier Disease to Acitretin through an Analogy between Close Relatives
}

\author{
Thiago Sande Miguel, Mateus de Oliveira Reis, Bruno Fonseca dos Santos, Aline da Silva Rocha, \\ Nayrton Kalys Cruz dos Anjos, Lívia Cristina de Melo Pino, Daniel Almeida da Costa
}

The Medical School at the Center of Higher Education of Valença, Valença, Brazil

Email: professordanielfmv@gmail.com

How to cite this paper: Miguel, T.S., Reis, M.O., dos Santos, B.F., Rocha, A.S., dos Anjos, N.K.C., Pino, L.C.M. and Costa, D.A. (2017) Evaluation of the Therapeutic Response and Improvement in the Quality of Life of the Patient with Darier Disease to Acitretin through an Analogy between Close Relatives. Journal of Biosciences and Medicines, 5, 4854.

https://doi.org/10.4236/jbm.2017.58004

Received: May 29, 2017

Accepted: August 1, 2017

Published: August 4, 2017

Copyright $\odot 2017$ by authors and Scientific Research Publishing Inc. This work is licensed under the Creative Commons Attribution International License (CC BY 4.0).

http://creativecommons.org/licenses/by/4.0/

\section{(c) (i) Open Access}

\begin{abstract}
Darier disease (DD), also known as follicular keratosis, is a rare autosomal dominant hereditary acantholytic dermatosis caused by a mutation in the ATP2A2 gene. Skin lesions are characterized by persistent confluent papules, preferentially located on the seborrheic areas of the face, chest and back. The hands, feet and nails are also commonly affected. DD has a chronic course with frequent relapses. Their treatment is often difficult and unsatisfactory. We present the case of a 54-year-old male with a history of keratotic papules with a brownish-black color, with a foul-smelling, pruritic and ardent appearance on the back and trunk, since the age of 19, which worsen in the summer. His 27-year-old daughter has a similar picture with her skin lesions started at age of 17 in the region below the breast, back, trunk, feet and hands. After the skin biopsy, the diagnosis was confirmed and acitretin $30 \mathrm{mg} /$ day was instituted. The importance of this case report is to alert health professionals that the diagnosis of DD should be considered in family members of patients, especially those in the first degree, and also in patients with follicular keratolytic dermatoses, being an important differential diagnosis of this group of patients diseases.
\end{abstract}

\section{Keywords}

Darier's Disease, Follicular Keratosis, Hereditary Dermatosis

\section{Introduction}

Darier disease (DD), also known as Darier-White disease and follicular kerato- 
sis, was first described in 1889. It is classified as a rare autosomal dominant inheritance genodermatosis related to the defective functioning of the calciumATPase-2 pump in the reticulum which is responsible for the acantholytic dyskeratosis seen in histopathology [1] [2]. Mainly characterized by fatty, brownish, hyperkeratotic, pruritic, and unpleasant odorous papules that group together to form verrucous-looking plaques, predominantly in seborrheic areas, areas of flexure, palmar region and plantar trunk and face [3] [4]. It also presents typical nails, oral mucosa changes [3], scalp involvement that can be severe, however hair loss is rare [1]. DD has a chronic course with frequent relapses. Based on the aforementioned clinical findings and the biopsy result, the diagnosis is established, which may reveal acantholytic dyskeratosis, hyperkeratosis, and focal parakeratosis [3]. Its treatment is often difficult and unsatisfactory [5], being oral Acitretin sometimes used to treat disseminated forms, with a significant improvement in patients' quality of life [6].

The present report aimed to demonstrate the clinical improvement as well as the improvement in quality of life, with the use of Acitretin, describing two cases in which the pathology was present, where, while in one of them the drug itself was used, in the other it wasn't, as a way to make an analogy between the quality of life in both cases.

\section{Case Reports}

\subsection{Case 1}

A 54-year-old male patient was referred to the dermatology outpatient clinic of the Luiz Gioseffi Januzzi School Hospital, at Valença medical school, Brazil complaining of keratotic papules and exiting 'pebbles' from cutaneous lesions. He says that the lesions began around the age of 19, progressively evolving. The papules were located in dorsal region and trunk, pruritic, with fetid smell and ardence. They were worse in the summer. The patient denied having had any type of treatment. He did not present comorbidities, such as systemic arterial hypertension and diabetes mellitus, he denied allergies. At the examination, the patient was in good general condition, afebrile, stained and hydrated mucosa, numerous papules and keratotic plaques located in dorsal region and trunk, brownish-black with irregular and rough surface, confluent and coalescing (Figure 1). The biopsy obtained from lesions of the upper back revealed hyperkeratosis, parakeratosis, papillomatosis, and formation of suprabasal vesicles (Figure 2). Based on the clinical findings and biopsy result, the patient was diagnosed with Darier's disease, but despite advised by the medical team, he chose not to adhere to the treatment with an inadequate and irregular clinical segment, which impaired an adequate propaedeutic of the treatment. In face of the clinical features of the pathology and the non-acceptance of the therapeutic measures, the patient had a persistence of the symptoms which culminated with the difficulty in social interaction, negatively affecting his quality of life, mainly due to the discomfort caused by the foul smell and the stinging of the lesions. 


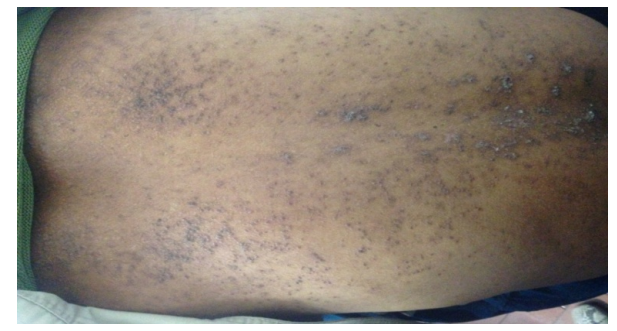

Figure 1. Multiple papules and blackish plaques in dorsal region.

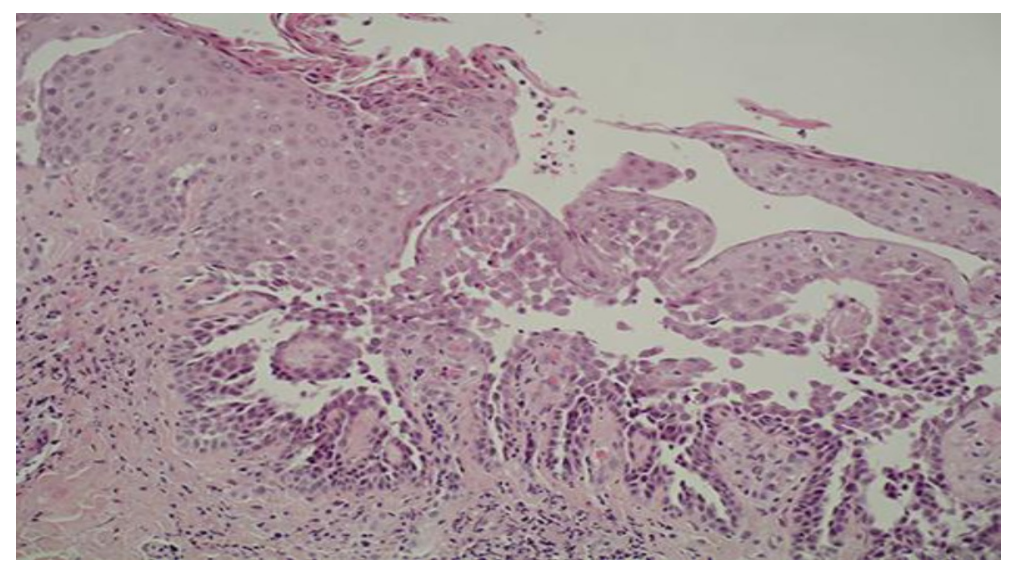

Figure 2. Hyperkeratosis, parakeratosis, papillomatosis, and formation of suprabasal vesicles.

\subsection{Case 2}

A 27-year-old female patient, the patient's daughter previously mentioned, was also referred to the same outpatient clinic mentioned above, with similar complaints as her father. She says the injuries started around the age of 17 . The erythematous papules were located in the front, below the breast, abdomen, hands and feet, pruritic, with a stinking odor and ardence, which according to the patient generated a sense of anguish and a sense of social exclusion, which negatively compromised their quality of life. They were worse in the summer. The patient denied having had any type of treatment. She did not present comorbidities, such as systemic arterial hypertension and diabetes mellitus, she denied allergies. The examination was in good general condition, afebrile, stained and hydrated mucosae, presence of numerous papules and keratotic plaques, erythematous (Figure 3) and some skin color, located in the frontal region, infra mammary, abdomen, hands and feet, with irregular and rough surface, scaly. Nails with distal V-border, alternating red and white bands, and onycholysis (Figure 4). A biopsy was performed from lesions of the infra-mammary region confirming the diagnosis of Darier's disease, and treatment with acitretin 30 $\mathrm{mg}$ /day was started. At the moment, it is still under treatment and observation of the therapeutic response to acitretin. It evolved with significant improvement of the picture in 1 month (Figure 5), which left the patient extremely satisfied and with improved quality of life. The patient is still under regular medical follow-up, with her clinical case presenting positive evolution every consultation. 


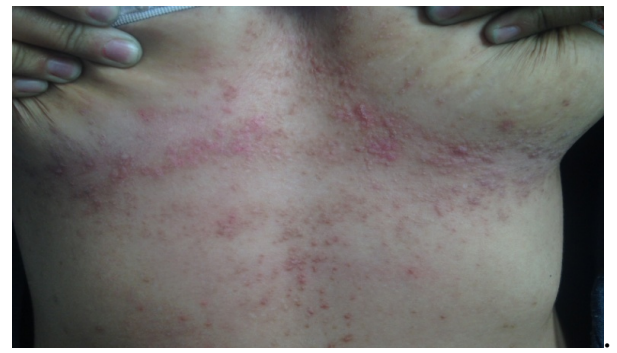

Figure 3. Numerous erythematous papules and keratotic plaques in the infra-mammary region.

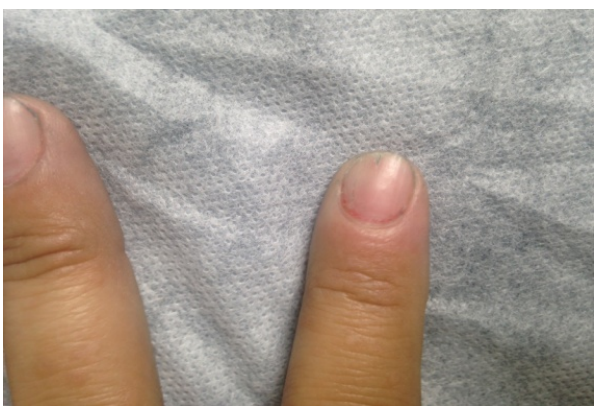

Figure 4. Nail with distal V-border and onicolicolysi.

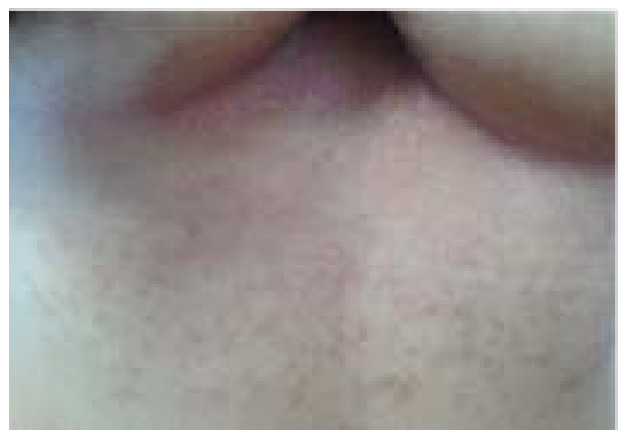

Figure 5. Regression of lesions after treatment with Acitretin.

It's worth to mention that both patients, of case 1 and 2, were previously and properly informed about their clinical paintings and their importance, agreeing with this publication, signing the Term of Free and Informed Consent.

\section{Discussion}

DD is transmitted through an autosomal dominant inheritance mechanism, with high penetrance and widely variable expression. [3] [7] [8], which can be corroborated in the case presented, since both the father and the daughter presented the pathology.

According to Burge [4], DD is rare, with an estimated prevalence between 1 in 55,000 and 1 in 100,000, and usually presents during the first two decades of life, although some cases that occurred in late adulthood have been reported. The disease rarely or never jumps a generation [3]. Both patients presented onset of the disease in young adulthood, and the patient's father presented progression of 
the disease, manifesting it even in later adult life, which does not escape rule, respecting the epidemiology referred to in the literature and the pattern of involvement in first degree relatives by the disease.

The clinical manifestations of DD are broad and variable. Hyperkeratotic, greasy skin papules are grouped in verrucous plaques, involving the seborrheic areas of the trunk and face, temporaries, ears and scalp [1] [9] [10]. The involvement of the hands, producing lesions similar to Hopf's verrucous acroceratosis, is seen in most patients [11]. The lesions tend to unite in thick and greasy plates that, in folds, can macerate, get infected and feel an unpleasant smell [12] [13]. The clinical aspect of this lesions, the form of their presentation, as well as their location, are compatible with what's described on the case, being compatible with the findings of the DD.

According to Cooper [3], the most common complaint associated with the disease is pruritus, with exacerbations attributed to heat, sweating, sunlight, lithium, steroid treatment, stress, and menstruation. In the present report, it can be verified that the symptoms of pruritus, both of the father and the daughter had an affront in the summer due to the increase in temperature, sweating and greater exposure to sunlight.

Nail changes include "v" distal border, alternating red and white bands, and onychololysis [14] [15], being these pathognomonic sings [3]. The patient presented the described nail injury, with a distal $\mathrm{V}$ edge on her fingernails, alternating from red to white stripes, and onycholysis, what strongly validated the diagnosis.

DD has been associated with neuropsychiatric manifestations, such as bipolar affective disorders, schizophrenia, psychosis and suicidal tendencies, which can be perceived, in smaller proportions in the patient, since it had its interpersonal relations impaired by your perception about the picture [16] [17].

Based on the clinical findings and the biopsy result the diagnosis is established. The main characteristic in the histopathology of DD is acantholytic dyskeratosis, hyperkeratosis and focal parakeratosis [3]. The evidenced clinical manifestations and the histopathological characteristics of the patients are compatible with that described in the literature, evidencing hyperkeraatosis, parakeratosis, papillomatosis and formation of suprabasal vesicle, which provides a basis for the diagnosis.

Basic measures to control DD include wearing sunscreen, wearing cotton clothing and avoiding hot environments e traumas. Drug treatment is done with the use of topical and oral retinoids, tacrolimus, topical 5-fluorouracil, calcipotriol [1] [3] [11] [18]. Oral retinoids, such as acitretin and isotretinoin, have been the most effective treatment for DD, reducing symptoms in $90 \%$ of the affected individuals. [19] [20]. Only the patient in case 2 adhered to non-pharmacological treatment and Medication with Acitretin $30 \mathrm{mg} /$ day, which leads to a remission of the patient's lesions and, consequently, to an improvement in their quality of life. The patient is still under regular medical follow-up, with her clinical case presenting 
positive evolution every consultation. However, the patient's father did not opt for the therapy, with persistence of symptoms, that culminated with the difficulty in social interaction, negatively affecting his quality of life, mainly due to the discomfort caused by the foul smell and the stinging of the lesions.

Goldsmith [21] describes that there are reports of surgery for DD treatment using laser dermabrasion, electrosurgery, cryosurgery and photodynamic therapy, therapies not necessary to control the pathology described in the report, due to the good response to the Acitretin approach.

\section{Conclusion}

Due to its genetic character, Darier's disease should be considered in the relatives of patients, especially those in the first degree, and should always perform the confirmation through a skin biopsy. Once diagnosed, early treatment with topical and systemic retinoids (acitretin or isotretinoin) should be instituted, which controls the exacerbation of the disease, improving the quality of life of the patients, since there is no cure but control of the disease. Because it is a follicular keratolytic dermatosis, it should be a differential diagnosis of several diseases such as: Hailey-Hailey's disease, benign familial pemphigus, verrucous disqueratoma and transient acantholytic dermatosis.

\section{Acknowledgements}

Thank to all who contributed directly or indirectly to the conclusion of this article.

\section{References}

[1] Sehgal, V.N. and Srivastava, G. (2005) Darier's (Darier-White) Disease/Keratosis Follicularis. International Journal of Dermatology, 44, 184-192. https://doi.org/10.1111/j.1365-4632.2004.02408.x

[2] Hohl, D. and Mauro, T. (2008) Darier Disease and Hailey-Hailey Disease. In: Bolognia, J.L., Jorizzo, J.L. and Rapini, R.P., Eds., Dermatology, 2nd Edition. Mosby Elsevier, Amsterdam, 791-800.

[3] Cooper, S.M. and Burge, S.M. (2003) Darier's Disease: Epidemiology, Pathophysiology, and Management. American Journal of Clinical Dermatology, 4, 97-105. https://doi.org/10.2165/00128071-200304020-00003

[4] Burge, S.M. and Wilkinson, J.D. (1992) Doença de Darier-White: uma Revisão dos Aspectos Clínicos em 163 Pacientes. The American Academy of Dermatology, 27, 40-50. https://doi.org/10.1016/0190-9622(92)70154-8

[5] Letule, V., Herzinger, T., Ruzicka, T. and Molin, S. (2013) Tratamento da Doença Darier com Alitretinoína Oral. Clinical and Experimental Dermatology, 38, 523 525. https://doi.org/10.1111/ced.12078

[6] Burge, S. (1999) Gestão da Doença de Darier. Clinical and Experimental Dermatology, 24, 53-56. https://doi.org/10.1046/j.1365-2230.1999.00416.x

[7] Karagiannidis, I., Brunner, M. and Zouboulis, C.C. (2016) Exacerbação da Doença da Doença de Darier sob a terapia de Interferon com Sinais Clínicos do Liquen Nitidus. Relatórios de Casos em Dermatologia, 8, 218-223. 
[8] Zheng, L., Jiang, H., Mei, Q. and Chen, B. (2015) Identificação de duas Novas Mutações Associadas à Doença de Darier No Gene ATP2A2. Molecular Medicine Reports, 12, 1845-1869.

[9] Judge, M.R., McLean, W.H.I. and Munro, C.S. (2010) Disorders of Keratinization. In: Burn, T., Breathnach, S., Cox, N. and Griffiths, C., Eds., Rook's Textbook of Dermatology, 8th Edition. Wiley-Blackwell, Oxford, 1981-1986. https://doi.org/10.1002/9781444317633.ch19

[10] Podgornii, A., Ciammella, P., Ramundo, D. and Iotti, C. (2013) Eficácia da Radioterapia na Doença de Darier: uma Evidência Indireta. Relatórios de Casos em Medicina Dermatológica.

[11] Weedon, D. (2010) Disorders of Epidermal Maturation and Keratinization. In: Weedon, D., Ed., Weedon's Skin Pathology, 3rd Edition. Churchill Livingstone, London, 267-268. https://doi.org/10.1016/B978-0-7020-3485-5.00010-3

[12] Linder, D., Marinello, E., Donisi, P.M., Salmaso, R., Zattra, E. and Zampetti, A. (2016) Dermatite Inframamária: Um Caso de Doença Localizada de Darier de Início Tardio. Relatórios de Casos em Dermatologia, 8, 189-192.

[13] Sehgal, V.N. and doença de Srivastava, G. (2005) Darier (Darier-White)/Foliar de Ceratose. International Journal of Dermatology, 44, 184-192. https://doi.org/10.1111/j.1365-4632.2004.02408.x

[14] Cohen, P.R. (2011) Longitudinal Erythronychia: Individual or Multiple Linear Red Bands of the Nail Plate: A Review of Clinical Features and Associated Conditions. American Journal of Clinical Dermatology, 12, 217-231. https://doi.org/10.2165/11586910-000000000-00000

[15] Medeiros, P.M., Alves, N.R., de M Trujillo, J.M., da Silva, C.C., de Faria, P.C.P. and da Silva, R.S. (2015) Doença de Darier Segmentar: Uma Apresentação de Diagnóstico Difícil. Anais Brasileiros de Dermatologia, 90, 62-65. https://doi.org/10.1590/abd1806-4841.20153581

[16] Gordon-Smith, K., Jones, L.A., Burge, S.M., Munro, C.S., Tavadia, S. and Craddock, N. (2010) The Neuropsychiatric Phenotype in Darier Disease. British Journal of Dermatology, 163, 515-522. https://doi.org/10.1111/j.1365-2133.2010.09834.x

[17] Yang, J.J.H., Lopes, R.S., Pereira, M.C.F., Tebcherani, A.J. and Pires, M.C. (2015) Doença de Darier Grave em um Paciente Psiquiátrico. Anais Brasileiros de Dermatologia, 90, 66-68. https://doi.org/10.1590/abd1806-4841.20153620

[18] Rubegni, P., Poggiali, S., Sbano, P., Risulo, M. and Fimiani, M. (2006) A Case of Darier's Disease Successfully Treated with Topical Tacrolimus. Journal of the European Academy of Dermatology and Venereology, 20, 84-87. https://doi.org/10.1111/j.1468-3083.2005.01352.x

[19] Woo, S.M., Won, C.H. and Cho, S. (2009) Darier: apresentação clínica variável e resultado fatal. Clinical and Experimental Dermatology, 34, 628-629.

[20] Kittridge, A., Wahlgren, C., Fuhrer, R., Zirwas, M. and Patton, T. (2010) Tratamento da Doença de Darier Recalcitrante com Terapia de Feixe de Elétrons. Terapia Dermatológica, 23, 302-304.

[21] Thappa, P. and Jeevankumar, B. (2000) Darier's Disease with Multiple Verrucae. The Journal of Dermatology, 27, 682-684. 
Submit or recommend next manuscript to SCIRP and we will provide best service for you:

Accepting pre-submission inquiries through Email, Facebook, LinkedIn, Twitter, etc. A wide selection of journals (inclusive of 9 subjects, more than 200 journals)

Providing 24-hour high-quality service

User-friendly online submission system

Fair and swift peer-review system

Efficient typesetting and proofreading procedure

Display of the result of downloads and visits, as well as the number of cited articles Maximum dissemination of your research work

Submit your manuscript at: http://papersubmission.scirp.org/

Or contact jbm@scirp.org 